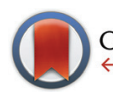

CrossMark $\leftarrow$ click for updates

Cite this: Dalton Trans., 2017, 46 1520

Received 22nd July 2016, Accepted 3rd January 2017

DOI: $10.1039 / c 6 d t 02905 a$

rsc.li/dalton

\section{Investigation of a new bis(carboxylate)triazole- based anchoring ligand for dye solar cell chromophore complexes $\uparrow$}

\author{
Alessandro Sinopoli, ${ }^{a}$ Fiona A. Black, ${ }^{\text {b }}$ Christopher J. Wood, ${ }^{\text {b }}$ Elizabeth A. Gibson ${ }^{\text {b }}$ \\ and Paul I. P. Elliott*a
}

A novel anchoring ligand for dye-sensitised solar cell chromophoric complexes, 1-(2,2'-bipyrid-4-yl)1,2,3-triazole-4,5-dicarboxylic acid (dctzbpy), is described. The new dye complexes $\left[\operatorname{Ru}(\mathrm{bpy})_{2}\right.$ (dctzbpy)][PF $]_{2}(\mathrm{AS} 16),\left[\mid \mathrm{r}(\mathrm{ppy})_{2}(\mathrm{dctzbpy})\right]\left[\mathrm{PF}_{6}\right](\mathrm{AS} 17)$ and $\left[\mathrm{Re}(\mathrm{dctzbpy})(\mathrm{CO})_{3} \mathrm{Cl}\right](\mathrm{AS} 18)$ were prepared in a two stage procedure with intermediate isolation of their diester analogues, AS16-Et 2, AS17-Et $_{2}$ and AS18-

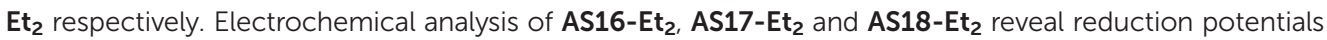
in the range -1.50 to $-1.59 \mathrm{~V}$ ( $v \mathrm{Vs}$. $\mathrm{Fc}^{+} / \mathrm{Fc}$ ) which are cathodically shifted with respect to that of the model complex $\left[\mathrm{Ru}(\mathrm{bpy})_{2}\left(\mathrm{dcbH}_{2}\right)\right]^{2+}(\mathbf{1})\left(E_{\text {red }}=-1.34 \mathrm{~V}, \mathrm{dcbH}_{2}=2,2^{\prime}\right.$ - bipyridyl-4,4'-dicarboxylic acid). This therefore demonstrates that the LUMO of the complex is correctly positioned for favourable electron transfer into the $\mathrm{TiO}_{2}$ conduction band upon photoexcitation. The higher energy LUMOs for AS16 to AS18 and a larger HOMO-LUMO gap result in blue-shifted absorption spectra and hence reduced light harvesting efficiency relative to their $\mathrm{dcbH}_{2}$ analogues. Preliminary tests on $\mathrm{TiO}_{2} \mathrm{n}$-type and $\mathrm{NiO} \mathrm{p}$-type DSSCs have been carried out. In the cases of the Ir(III) and Re(I) based dyes AS17 and AS18 these show inferior performance to their $\mathrm{dcbH}_{2}$ analogues. However, the $\mathrm{Ru}(\|)$ dye $\mathrm{AS} 16$ ( $\left.\eta=0.61 \%\right)$ exhibits significantly greater efficiency than $1(\eta=0.1 \%)$. In a p-type cell AS16 shows the highest photovoltaic efficiency $(\eta=0.028 \%)$, almost three times that of cells incorporating the benchmark dye coumarin C343.

\section{Introduction}

The application of transition metal complexes, principally those of ruthenium(II), have attracted enormous attention for their application in n-type dye-sensitised solar cells (DSSC). ${ }^{1-4}$ The relatively long-lived triplet metal-to-ligand charge-transfer $\left({ }^{3}\right.$ MLCT) states of these complexes ${ }^{5}$ allow efficient charge injection into the electrode on which the complex is adsorbed. Innumerable reports have appeared in the literature on the design and modification of the ligand set for these complexes in order to enhance the optical absorption cross-section to increase light harvesting efficiency and to optimise the ground state and excited state oxidation potentials for charge-injection and dye regeneration processes. ${ }^{6} \mathrm{~A}$ critical component of these dye complexes is therefore the ligand on which the ${ }^{3} \mathrm{MLCT}$ state is localised and which anchors the complexes to the elec-

\footnotetext{
${ }^{a}$ Department of Chemistry, University of Huddersfield, Queensgate, Huddersfield, HD1 3DH, UK. E-mail: p.i.elliott@hud.ac.uk

${ }^{b}$ School of Chemistry, Newcastle University, Newcastle upon Tyne, NE1 TRU, UK.

E-mail: elizabeth.gibson@ncl.ac.uk

$\dagger$ Electronic supplementary information (ESI) available. See DOI: 10.1039/ c6dt02905a
}

trode. The energy of the lowest-unoccupied molecular orbital (LUMO) of the dye, localised on this ligand then largely determines the excited state oxidation potential which must be correctly positioned relative to the Fermi level of the electrode to favour efficient charge injection, and relative to the electrolyte redox couple to minimise short-circuit reactions. Whilst complexes of ruthenium dominate the literature dyes based on a variety of metals have been evaluated including osmium, ${ }^{7}$ platinum, ${ }^{8}$ rhenium,${ }^{9}$ iron, ${ }^{10}$ and iridium ${ }^{11}$ as well as zinc porphyrins. ${ }^{12}$ Great strides have also been taken in the optimisation of metal free organic dyes. ${ }^{13,14}$

Over thirty years ago, Goodenough and co-workers ${ }^{15}$ reported the use of 4,4'-dicarboxy-2,2'-bipyridine $\left(\mathrm{dcbH}_{2}\right.$, Fig. 1) as an ambidentate ligand for coordination to $\mathrm{Ru}(\mathrm{II})$ and metal oxide semiconductors. Strong electronic coupling between the MLCT excited states of $\mathrm{dcbH}_{2}$-containing $\mathrm{Ru}$ compounds and $\mathrm{TiO}_{2}$ has been inferred from femtosecond transient absorption spectroscopy, and the timescales extracted from such data are on the order of $<25 \mathrm{fs}{ }^{16}$ To this day $\mathrm{dcbH}_{2}$ remains the most efficient and widely utilised anchoring ligand for applications in DSSCs, however, a number of other carboxylate-based variant ligands have been investigated. Heuer et al. reported the design of a new bipyridine based 

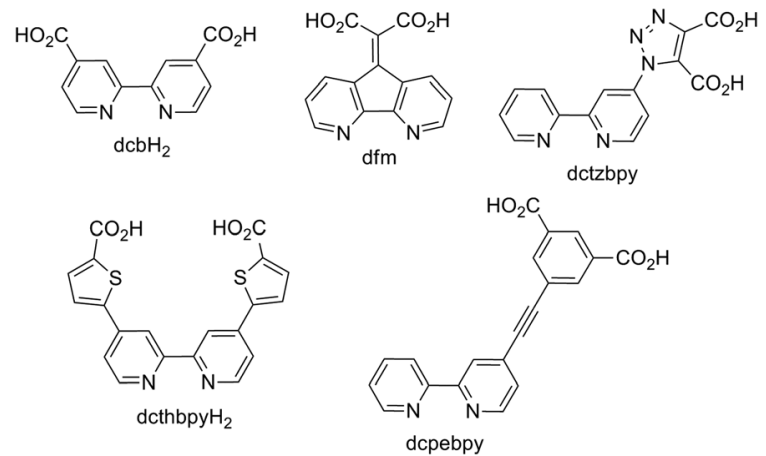

Fig. 1 Structures of selected carboxylate-based DSSC anchoring ligands.

anchoring ligand (4,5-diazafluoren-9-ylidene)malonic acid (dfm, Fig. 1) together with its corresponding complex $\left[\mathrm{Ru}(\mathrm{bpy})_{2}(\mathrm{dfm})\right]^{2+}\left(\mathrm{bpy}=2,2^{\prime}\right.$-bipyridyl $){ }^{6}$ Mishra et al. prepared the complex BCT-1, $\left[\mathrm{Ru}(\mathrm{dcthbpyH})_{2}(\mathrm{NCS})_{2}\right]\left[\mathrm{NBu}_{4}\right]_{2}$, where the distance between the bpy core of the ligand and its anchoring carboxylate group has been extended by the introduction of a thiophene spacer $\left(\right.$ dcthbpyH $\left._{2}\right){ }^{17}$ This increases charge separation upon charge injection and reduces the rate of recombination but also leads to augmentation of the light absorption properties over the corresponding $\mathrm{dcbH}_{2}$ complex. This yielded an overall conversion efficiency of $6.1 \%$ compared with the $4.8 \%$ achieved using the archetypal DSSC dye N3 $\left(\left[\mathrm{Ru}\left(\mathrm{dcbH}_{2}\right)_{2}(\mathrm{NCS})_{2}\right]\right)$. In an attempt to minimise the rate constant for charge recombination, Abrahamsson et al. introduced a phenylenethynylene unit between a bpy ligand and the surface anchoring groups (dcpebpy, Fig. 1), preparing the corresponding $\left[\mathrm{Ru}(\text { dcebpy)(bpy)(NCS })_{2}\right]$ complex. This resulted in a recombination rate three times smaller compared to that for N3. ${ }^{18}$

Whilst carboxylates represent by far the most commonly encountered anchoring moiety DSSC dyes with other anchoring groups have also been investigated. These include phoshonic acid appended copper(I) and ruthenium(II) complexes ${ }^{19-21}$ and also boronic acid derivatised complexes. ${ }^{22}$

In contrast to the wealth of literature on transition metalbased dyes for n-type DSSCs, only a few examples have been reported for NiO p-type cells. ${ }^{23-30}$ Pellegrin et al. have reported ruthenium(II)-based sensitisers for p-type DSSC devices with phosphonic acid, thiocarboxylate and catechol derived anchoring groups. ${ }^{29} \mathrm{Ji}$ et al. have reported cyclometalated ruthenium complexes of the type $\left[\mathrm{Ru}\left(\mathrm{N}^{\wedge} \mathrm{N}\right)_{2}\left(\mathrm{C}^{\wedge} \mathrm{N}\right)\right]^{+}$as sensitisers for p-type DSSCs. ${ }^{28}$ Addition of a rigid biphenylene spacer between the carboxylate anchor and the aryl ring of the cyclometalated ligand led to a marked increase in device efficiency ( $0.05 \%$ compared to $0.009 \%$ with no spacer). Recently Wood et al. reported bis(bidentate) ruthenium(II) based dye complexes bearing electron rich carboxylate derivatised triarylamine anchoring groups yielding efficiencies of up to $0.09 \% .^{27}$ Massin et al. have also reported carboxylate-appended triarylamine functionalised dyes with a $\left[\left(\mathrm{Ph}_{2} \mathrm{C}=\mathrm{C}=\mathrm{Ru}(\mathrm{dppe})_{2}\right)\right]$ core (dppe $=1,2$-bis (diphenylphosphino)ethane) ${ }^{25}$
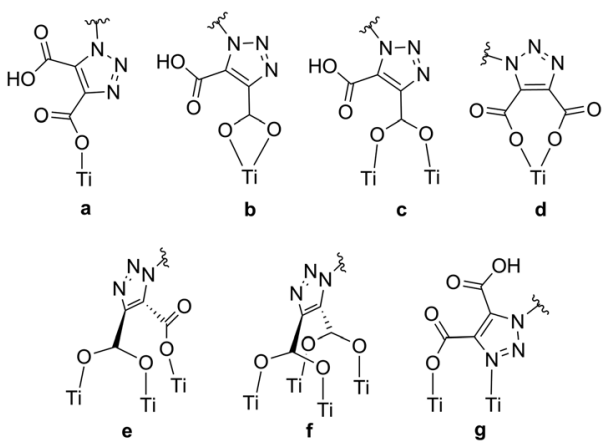

Fig. 2 Selection of the potential $\mathrm{TiO}_{2}$ anchoring modes that could be adopted by the dctzbpy ligand.

Through the use of triazole-based "click" chemistry ${ }^{31}$ we report here the design and synthesis of the novel anchoring ligand (2,2'-bipyrid-4-yl)-1,2,3-triazole-4,5-dicarboxylic acid (dctzbpy, Fig. 1). Triazole moieties have been utilised in conjugated polymers and results suggested that the linkage is somewhat electronically insulating. ${ }^{32,33}$ Whilst this might be expected to impair to some extent the rate of charge injection into $\mathrm{TiO}_{2}$ for an immobilised dye, this could significantly retard recombination reactions thereby enhancing overall photovoltaic efficiency. The designed anchor ligand also presents conformational freedom that would enable multiple possibilities for $\mathrm{TiO}_{2}$ surface coordination modes to be envisaged. For example, the various possibilities for coordination by one carboxylate group (monodentate (a), bidentate (b) or bridging (c) in Fig. 2), both carboxylate groups (bidentate (d), tridentate (e), tetradentate (f)) or anchoring through the 4-position carboxylate with additional surface coordination of the triazoleN3 atom (g) could result in highly favourable adsorption characteristics. Further anchoring modes through hydrogen bonding between carboxylic acid and surface oxygen atoms or carboxylate with surface hydroxyl groups can also be envisaged.

We also report the preparation of ruthenium(II), iridium(III) and rhenium(I) complexes $\mathbf{A S 1 6}-\mathbf{E t}_{\mathbf{2}}$ to $\mathbf{A S 1 8 - \mathbf { E t } _ { \mathbf { 2 } }}$ of the initial diethyl ester of the dctzbpy ligand and subsequent photophysical and electrochemical analyses. Further, we report the hydrolysis of these complexes to their corresponding diacids AS16 to AS18 (Fig. 3) and pilot studies on their utilisation in DSSC test devices with comparison to corresponding $\mathrm{dcbH}_{2}$ complexes 1 to 3 .

\section{Results \& discussion}

The above mentioned ligand, dctzbpy, was prepared by the route described in Scheme 1. We, and others, have previously reported the preparation and reactivity of the bpy derivative 4-azido-2,2'-bipyridyl. ${ }^{34,35}$ This azide precursor was subject to thermally driven cycloaddition with one equivalent of diethyl acetylenedicarboxylate in refluxing toluene to furnish the diester diethyl-1-(2,2'-bipyrid-4-yl)-1,2,3-triazole-4,5-dicarboxy- 

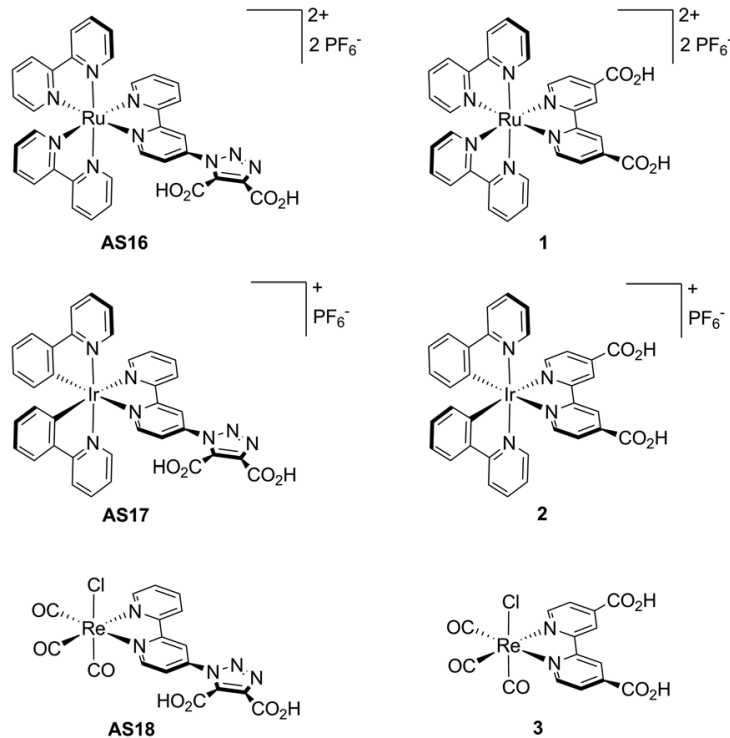

Fig. 3 Structure of complexes AS16-18 and their $\mathrm{dcbH}_{2}$ analogues 1-3.

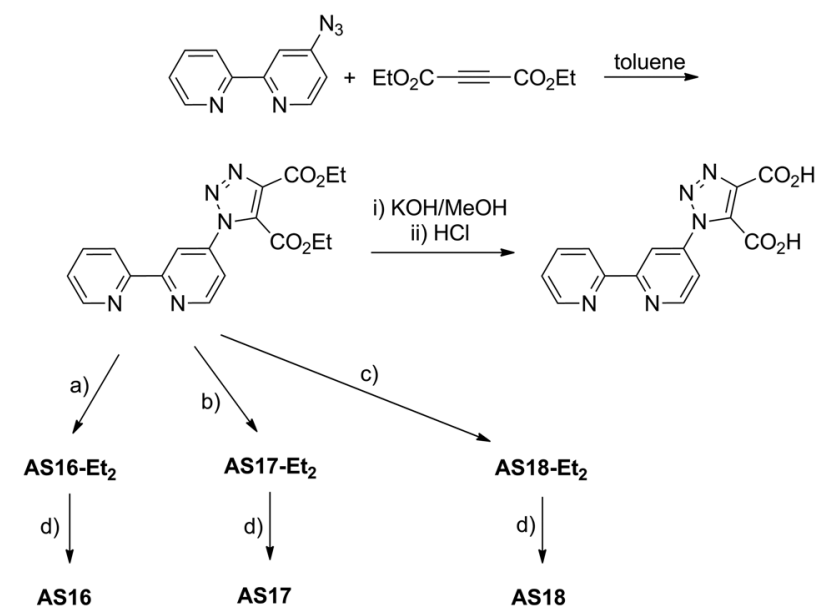

Scheme 1 Synthesis of the target 1-(2,2'-bipyrid-4-yl)-1,2,3-triazole4,5-dicarboxylic acid ligand and complexes AS16 to AS18: (a) (i) [Ru (bpy) ${ }_{2} \mathrm{Cl}_{2}$ ], EtOH, reflux, (ii) $\mathrm{NH}_{4} \mathrm{PF}_{6}, \mathrm{MeOH}$; (b) (i) $\left[\operatorname{lr}(\mathrm{ppy})_{2} \mathrm{Cl}_{2}, \mathrm{CH}_{2} \mathrm{Cl}_{2} /\right.$ $\mathrm{MeOH}$, reflux, (ii) $\mathrm{NH}_{4} \mathrm{PF}_{6}, \mathrm{MeOH}$; (c) $\left[\mathrm{Re}(\mathrm{CO})_{5} \mathrm{Cl}\right]$, toluene, reflux; (d) (i) $\mathrm{KOH} /$ acetone, $\mathrm{HCl}$, (ii) $\mathrm{NH}_{4} \mathrm{PF}_{6}$.

late. Cycloaddition was confirmed by infrared spectroscopy with the disappearance of the azide stretch corresponding to the starting material $\left(2115 \mathrm{~cm}^{-1}\right)$ and the appearance of new CO stretching bands for the carboxylate substituents on the triazole ring $\left(1735 \mathrm{~cm}^{-1}\right)$. The ester groups then underwent hydrolysis to the corresponding carboxylic acids in refluxing dilute $\mathrm{KOH}$ in methanol before neutralising with $\mathrm{HCl}$.

The ${ }^{1} \mathrm{H}$ NMR spectrum of the product shows seven unique environments (ESI $\dagger$ ) for the protons on the bipyridyl fragment along with two sets of signals for the ethyl groups of the ester moieties. This is consistent with the cycloaddition of the acetylene to form the triazole and loss of magnetic equivalence of the two carboxylate groups. The resonances for the triazoleappended pyridine ring appear at $\delta 8.85,8.67$ and 7.61 and are shifted as a result of the cycloaddition relative to those of the azide starting material $(\delta 8.69,8.15$ and 7.34$) .{ }^{35}$

Routes to ruthenium, iridium and rhenium detzbpy complexes $\left[\mathrm{Ru}(\mathrm{bpy})_{2}(\right.$ dctzbpy $\left.)\right]\left[\mathrm{PF}_{6}\right]_{2}$ (AS16), $\left[\operatorname{Ir}(\text { ppy })_{2}(\right.$ detzbpy) $]\left[\mathrm{PF}_{6}\right]$ (AS17, ppyH $=$ 2-phenylpyridine) and $\left[\mathrm{Re}(\mathrm{CO})_{3}(\right.$ detzbpy $\left.) \mathrm{Cl}\right]$ (AS18) respectively were investigated involving direct reaction of the acid form of the ligand with precursor complexes, however, isolation of the corresponding complexes proved problematic. Isolation of complexes of the intermediate diester ligand, AS16-Et ${ }_{2}, \mathbf{A S 1 7}_{-\mathbf{E t}_{\mathbf{2}}}$ and $\mathbf{A S 1 8 - \mathbf { E t } _ { \mathbf { 2 } }}$, followed by hydrolysis was deemed to give better results. Thus, two-step syntheses starting from $\left[\mathrm{Ru}(\mathrm{bpy})_{2} \mathrm{Cl}_{2}\right],\left[\operatorname{Ir}(\mathrm{ppy})_{2} \mathrm{Cl}\right]_{2}$ and $\left[\mathrm{Re}(\mathrm{CO})_{5} \mathrm{Cl}\right]$ were carried out. Firstly, the above mentioned starting metal precursor complexes were reacted together with detzbpy (Scheme 1) followed by anion metathesis with $\mathrm{NH}_{4} \mathrm{PF}_{6}$ to yield the desired diester complexes.

As a consequence of the asymmetry of the detzbpy ligand the $\left[\mathrm{Ru}(\mathrm{bpy})_{2}\right]$ and $\left[\operatorname{Ir}(\mathrm{ppy})_{2}\right]$ fragments in AS16-Et $\mathbf{2}_{\mathbf{2}}$ and AS17$\mathbf{E t}_{\mathbf{2}}$ do not possess the $C_{2}$ symmetry present in $\mathbf{1}$ and 2 . Hence,

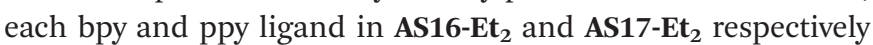
is magnetically unique resulting in complicated ${ }^{1} \mathrm{H}$ NMR spectra due to the overlap of signals (ESI $\dagger$ ). The ${ }^{1} \mathrm{H}$ NMR spectrum of $\mathbf{A S 1 8}_{\mathbf{2}} \mathbf{E t}_{\mathbf{2}}$ exhibits detzbpy signals shifted to higher field in comparison with the free diester ligand by $\sim 0.4 \mathrm{ppm}$ with the resonances for the H-6 and H-6' position appearing at $\delta 9.21$ and 9.06 respectively.

The final dyes AS16 to AS18 can be readily accessed by hydrolysis with $\mathrm{KOH}$ in acetone and subsequent neutralisation. Due to solubility issues, however, and the fact that key properties are expected to differ little after hydrolysis electrochemical characterisation is reported for the more soluble

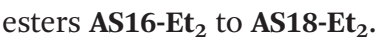

Cyclic voltammetry traces and summarised electrochemical data are presented in Fig. 4 and Table 1 respectively. The complex AS16-Et $\mathbf{E}_{2}$ presents a reversible $\mathrm{Ru}(\mathrm{II}) /(\mathrm{III})$ oxidation at $+1.00 \mathrm{~V}$ and an irreversible reduction peak at $-1.50 \mathrm{~V}$ assigned to the detzbpy reduction. This is followed by two further reversible reduction peaks assigned to the bpy ligands. A

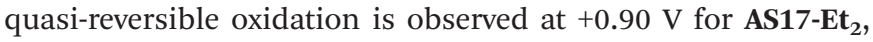
corresponding to the one-electron $\operatorname{Ir}(\mathrm{III}) / \operatorname{Ir}(\mathrm{IV})$ couple. The first reduction presents as a quasi-reversible process at $-1.59 \mathrm{~V}$ again assigned to be detzbpy ligand. Complex $\mathbf{A S 1 8}_{\mathbf{E}} \mathbf{E t}_{\mathbf{2}}$ is

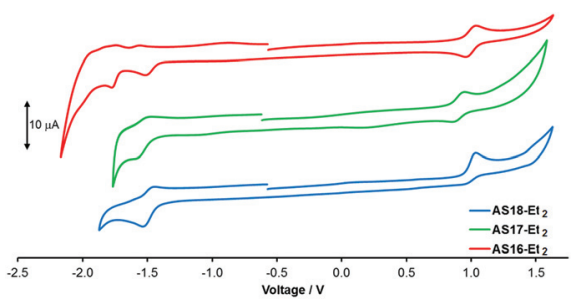

Fig. 4 Cyclic voltammetry traces for complexes AS-16-Et $t_{2}, \mathrm{AS} 17-\mathrm{Et}_{2}$ and $\mathrm{AS}_{18}-\mathrm{Et}_{2}$ vs. $\mathrm{Fc}^{+} / \mathrm{FC}=0.0 \mathrm{~V}$. 
Table 1 Summarised electrochemical data for complexes AS16-Et $\mathrm{E}_{2}$ to $\mathrm{AS}_{18}-\mathrm{Et}_{2}$ at room temperature acetonitrile $\mathrm{vs} . \mathrm{Fc}^{+} / \mathrm{Fc}=0.0 \mathrm{~V}$

\begin{tabular}{lcc}
\hline Dye & $E_{\text {ox }} / \mathrm{V}$ & $E_{\text {red }} / \mathrm{V}$ \\
\hline AS16-Et & 1.00 & -1.50 \\
AS17-Et $_{2}$ & 0.90 & -1.59 \\
AS18-Et $_{2}$ & 1.00 & -1.56
\end{tabular}

characterised by a quasi-reversible oxidation peak at $+1.00 \mathrm{~V}$, in agreement with the potential of other $\operatorname{Re}(\mathrm{CO})_{3}\left(\mathrm{dcb}-\mathrm{Et}_{2}\right) \mathrm{X}$ based complexes $\left(\mathrm{X}=\right.$ halide). ${ }^{36}$ It also presents a reversible detzbpy-based reduction at $-1.56 \mathrm{~V}$. The oxidation potentials for these complexes are similar to those of their corresponding $\mathrm{dcbH}_{2}$-based analogues consistent with the expectation of a largely metal-based HOMO. ${ }^{29,36,37}$ The detzbpy-based reduction potentials $(-1.5$ to $-1.6 \mathrm{~V})$ are more cathodically shifted than that reported for $\mathbf{1}(-1.34 \mathrm{~V})^{29}$ consistent with a higher energy LUMO as indicated in the spectroscopic data. ${ }^{17-19}$

The isolated and purified complexes AS16-Et ${ }_{2}$ to $\mathbf{A S 1 8 - \mathbf { E t } _ { 2 }}$ were then refluxed in $\mathrm{KOH} /$ acetone and neutralised with $\mathrm{HCl}$ to yield the corresponding dctzbpy complexes. The analogous $\mathrm{dcbH}_{2}$ complexes $\left[\mathrm{Ru}(\mathrm{bpy})_{2}\left(\mathrm{dcbH}_{2}\right)\right]\left[\mathrm{PF}_{6}\right]_{2} \quad(\mathbf{1}),{ }^{29} \quad\left[\operatorname{Ir}(\mathrm{ppy})_{2}\right.$ $\left.\left(\mathrm{dcbH}_{2}\right)\right]\left[\mathrm{PF}_{6}\right](2)^{20}$ and $\left[\operatorname{Re}(\mathrm{CO})_{3}\left(\mathrm{dcbH}_{2}\right)(\mathrm{Cl})\right](3)^{17}$ were also prepared for comparison. UV-Visible absorption spectra were recorded for all complexes in acetonitrile solutions at room temperature and are presented in Fig. 5 with summarised data listed in Table 2.

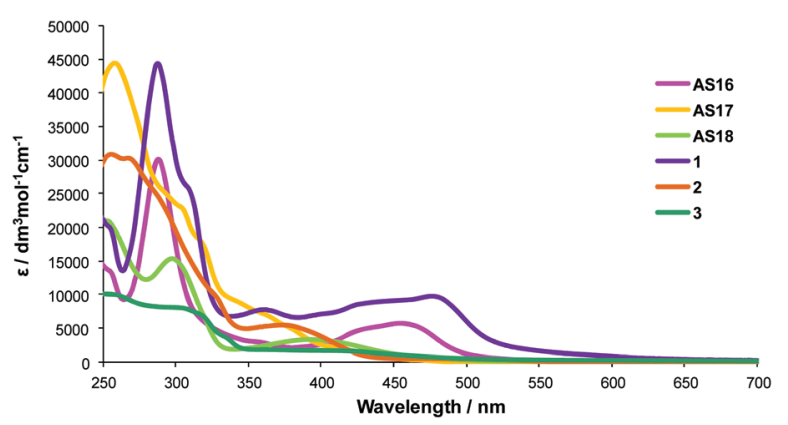

Fig. 5 UV-visible absorption spectra for complexes AS16-18 and 1-3 in acetonitrile solutions.

Table 2 Summarised photophysical data for complexes AS16-18 and their $\mathrm{dcbH}_{2}$ analogues 1-3 at room temperature in acetonitrile

\begin{tabular}{llll}
\hline Complex & $\lambda^{\mathrm{abs}} / \mathrm{nm}\left(\varepsilon / \mathrm{dm}^{3} \mathrm{~mol}^{-1} \mathrm{~cm}^{-1}\right)$ & $\lambda_{\max }^{\mathrm{em}} / \mathrm{nm}$ & $\tau / \mathrm{ns}$ \\
\hline $\mathbf{1}$ & $245(21923), 287(44481), 308(26079)$, & 682 & 32 \\
$\mathbf{2}$ & $357(7836), 430(8807), 475(9880)$ & & \\
$\mathbf{3}$ & $256(30778), 289(24016), 377(6905)$ & 689 & 33 \\
AS16 & $252(10289), 303(8202), 413(1826)$ & 725 & 35 \\
\multirow{2}{*}{ AS17 } & $242(15624), 287(30138), 424(4642)$, & 638 & 34 \\
& $456(5719)$ & & \\
AS18 & $255(44311), 301(23330), 364(7771)$, & 590 & 25 \\
& $254(1914)$ & & \\
& $25204), 297(15317), 397(3815)$ & 553 & 38
\end{tabular}

The comparison between the $\mathrm{dcbH}_{2}$ complexes and their detzbpy analogues shows similar absorption profiles but with a slight blue shift in the lower energy absorptions for complexes AS16-18. All complexes show a strong band at 250-300 nm attributed to $\pi-\pi^{*}{ }^{1} \mathrm{LC}$ transitions together with ${ }^{1}$ MLCT bands of modest intensity $\left(\varepsilon \approx 5000-10000 \mathrm{dm}^{3} \mathrm{~mol}^{-1}\right.$ $\mathrm{cm}^{-1}$ ) above $400 \mathrm{~nm}$. The blue-shifted absorption bands in the spectra of the detzbpy complexes suggests that the LUMO is higher in energy than those for the $\mathrm{dcbH}_{2}$ analogues and that the biscarboxytriazole group is less electron withdrawing than the two carboxylate groups bonded directly to the bipyridyl core in $\mathrm{dcbH}_{2}$. Nevertheless, LUMO is correctly positioned with reference to the $\mathrm{TiO}_{2}$ Fermi level for favourable charge injection when adsorbed on a photoanode. ${ }^{4}$ These similar absorption patterns will be expected to result in comparable photovoltaic performance for the dyes AS16-18 relative to 1-3.

The complexes AS16-18 exhibit broad emission bands between 550 and $650 \mathrm{~nm}$ which are similarly blue-shifted relative to their $\mathrm{dcbH}_{2}$ analogues, with similar life-times at about $32 \mathrm{~ns}$. This again is indicative that the LUMO of the detzbpy ligand, and thus that of its complexes, is higher in energy with respect to $\mathrm{dcbH}_{2}$ thereby leading to the observed destabilisation of ${ }^{3}$ MLCT $\mathrm{T}_{1}$ states in these complexes.

In order to gain a more complete understanding of the photophysical and electrochemical properties imparted by the new ligand dctzbpy we turned to density functional theory (DFT) calculations. These calculations were carried out on the free acid carboxylic acid complexes AS16-18, partly to reduce computational cost of the extra alkyl groups of the ester moieties, and due to the fact that the spectroscopic absorption properties of the free acid and ester complexes differ little suggesting that they are electronically very similar. Optimised singlet ground state geometries for the three new dyes AS16-18 and model complexes 1-3 were calculated at the B3LYP level of theory using Stuttgart-Dresden relativistic small-core effective core potentials and basis sets for the metallic elements and $6-311 \mathrm{G}^{*}$ basis sets for all other atoms. Molecular orbital energies (Fig. 6) and localisations (Fig. 7) were then determined in single-point calculations using the COSMO solvation model ( $\varepsilon=37.5$ for acetonitrile). The HOMO has significant metallic d-orbital character in all cases with additional aryl $\pi^{*}$ character in the case of AS17 and CO $\pi^{*}$ and $\mathrm{Cl}$ p-orbital character for AS18. In all cases the LUMO is dominated by the dctzbpy ligand and is mostly localised over the bpy fragment. For AS16 there is also a minor contribution

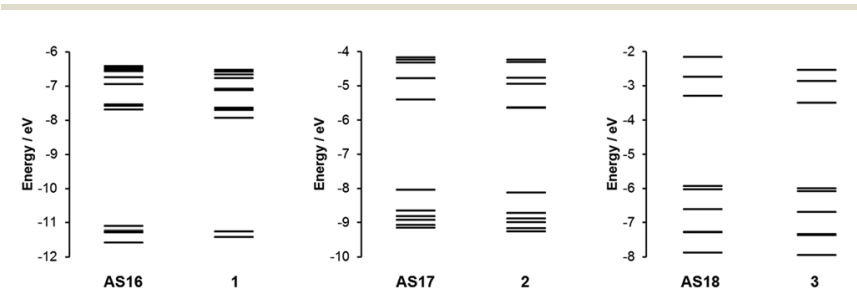

Fig. 6 Calculated molecular orbital energy level diagram for complexes AS16-18 and 1-3. 

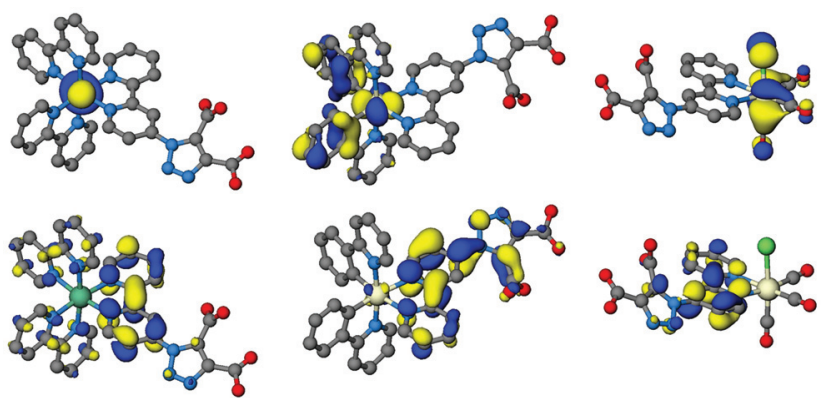

AS16

AS17

AS18

Fig. 7 Optimised geometries and plots of HOMO (top) and LUMO (bottom) orbitals for complexes AS16 to AS18.

from the bpy ligands whilst for AS17 and AS18 there is an additional contribution from the dicarboxytriazole moiety.

Frontier molecular orbital energies are provided in Table 3. In agreement with UV-visible absorption and emission data there is a slight destabilization of both HOMO and LUMO orbitals, but to a greater extent for the latter, for AS16-18 relative to those of their $\mathrm{dcbH}_{2}$ analogues. Thus the HOMOLUMO gaps for the dctzbpy complexes are an average of $0.12 \mathrm{eV}$ larger than for 1-3 accounting for the experimental spectroscopic data. The ground state frontier molecular orbitals of AS16-18 are thus correctly localised to facilitate optimum charge-transfer directionality with respect to the carboxylate anchor for efficient charge injection when adsorbed onto a photoanode. Moreover, the relative energy of the dctzbpy ligand localised LUMO in complexes AS16-18, being slightly higher than those of the $\mathrm{dcbH}_{2}$ analogues 1 to 3 , will inevitably be favourably positioned relative the $\mathrm{TiO}_{2}$ Fermi level in order to facilitate charge injection into the electrode.

Time-dependent DFT (TDDFT) calculations were carried out on the optimised ground state geometries of each complex in order to determine vertical excitation energies and the nature of the lowest energy singlet excited states. Simulated absorption spectra are overlaid with experimental spectra and shown in Fig. 8 and reveal that predicted transitions correlate well with the experimental spectra. The excitations to the $S_{1}$ state of all complexes are primarily HOMO $\rightarrow$ LUMO in character, however, they are of low oscillator strength and will therefore contribute little to the observed absorption spectra. Consistent with the enlarged HOMO-LUMO gap in complexes AS16-18 relative to their respective $\mathrm{dcbH}_{2}$ analogues the $\mathrm{S}_{1}$ transitions

Table 3 Calculated HOMO and LUMO energies for complexes AS16-18 and 1-3

\begin{tabular}{llll}
\hline Dye & LUMO/eV & HOMO/eV & HOMO-LUMO $/ \mathrm{eV}$ \\
\hline $\mathbf{1}$ & -7.92 & -11.26 & 3.33 \\
AS16 & -7.68 & -11.10 & 3.42 \\
$\mathbf{2}$ & -5.65 & -8.13 & 2.48 \\
AS17 & -5.41 & -8.04 & 2.63 \\
$\mathbf{3}$ & -3.51 & -6.00 & 2.49 \\
AS18 & -3.30 & -5.94 & 2.64
\end{tabular}
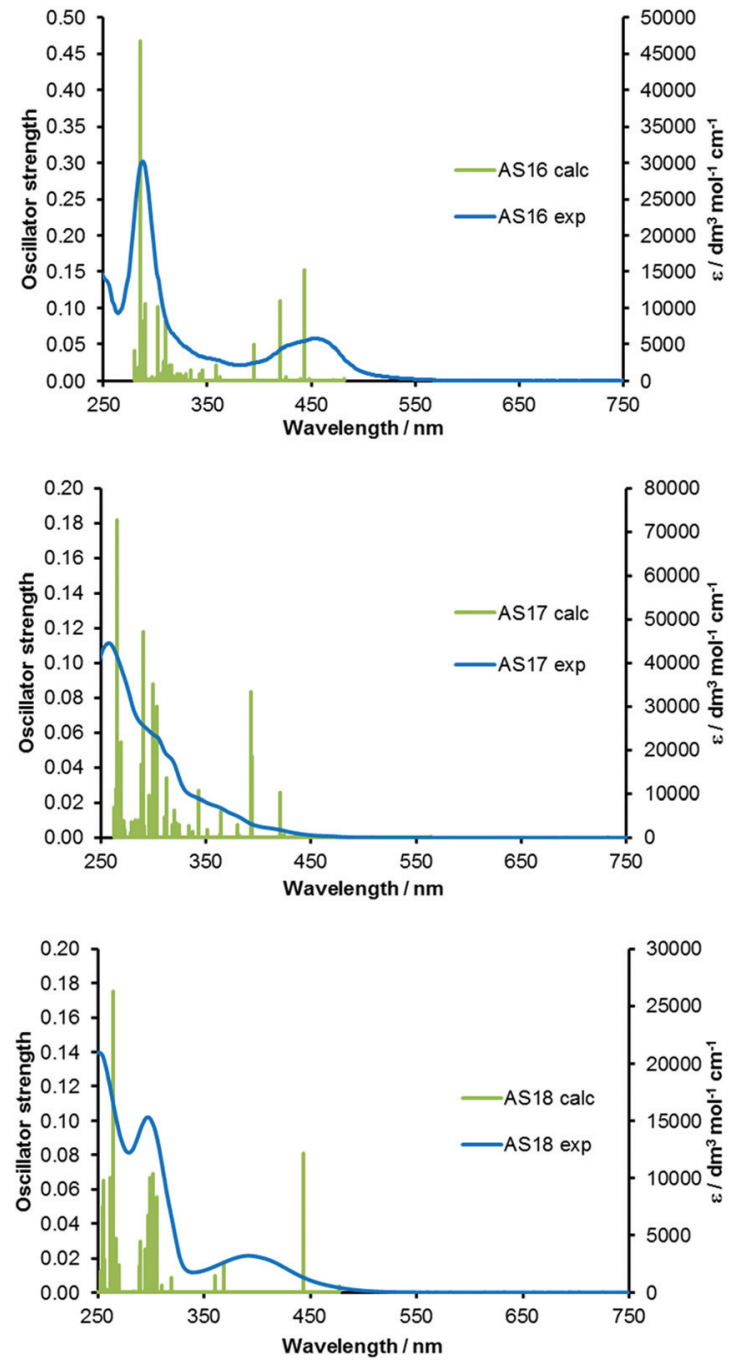

Fig. 8 TDDFT calculated absorption spectra for complexes AS16-18 with experimental spectra overlaid.

occur at shorter wavelengths. The major transitions observed for all complexes between 350 and $550 \mathrm{~nm}$ are primarily of ${ }^{1}$ MLCT character. Higher energy intense absorptions (240 to $350 \mathrm{~nm}$ ) are assigned as having predominantly ${ }^{1} \mathrm{LC} \pi \rightarrow \pi^{*}$ character. The ruthenium complex AS16 presents two dominating transitions at $452\left(\mathrm{~S}_{5}\right)$ and $412\left(\mathrm{~S}_{8}\right)$ nm respectively, involving primarily HOMO-2 $\rightarrow$ LUMO $+2{ }^{1}$ MLCT character. The iridium complex AS17 exhibits one transition at $421 \mathrm{~nm}\left(\mathrm{~S}_{4}\right)$ of mainly HOMO-1 $\rightarrow$ LUMO ${ }^{1} \mathrm{MLCT} /{ }^{1} \mathrm{LLCT}$ character and two transitions at $394\left(\mathrm{~S}_{5}\right)$ and $393\left(\mathrm{~S}_{6}\right) \mathrm{nm}$ with ${ }^{1} \mathrm{MLCT} /{ }^{1} \mathrm{ILCT}$ and ${ }^{1} \mathrm{MLCT} /{ }^{1} \mathrm{LLCT}$ character respectively. The rhenium complex AS18 exhibits a strong transition at $443 \mathrm{~nm}\left(\mathrm{~S}_{2}\right)$ with a predominant composition of HOMO-1 $\rightarrow$ LUMO ${ }^{1}$ MLCT character.

The relative positioning of the frontier orbitals in the dctzbpy complexes described would indeed seem to make them amenable to application in the photovoltaic sensitisation of n-type solar cells. We therefore prepared n-type $\mathrm{TiO}_{2}$-based test DSSC devices utilising complexes AS16 to AS18 along with those of the corresponding $\mathrm{dcbH}_{2}$ analogues for comparison. 
The free dye AS16 and $\mathrm{TiO}_{2}$-immobilised AS16 were analysed by FTIR spectroscopy and microscopy in an attempt to gain insight into the anchoring mode of the dctzbpy ligand. Unfortunately the data do not enable any definitive conclusions to be drawn.

The principle photovoltaic parameters for the constructed DSSC devices are listed in Table 4. The overall conversion efficiencies $\eta$ were derived from the equation $\eta=J_{\mathrm{sc}} V_{\mathrm{oc}} \mathrm{FF}$, where $J_{\mathrm{sc}}$ is the short circuit current density, $V_{\mathrm{oc}}$ is the open circuit voltage, and FF is the fill factor. Fig. 9 shows the photocurrent-voltage and IPCE traces of the n-type DSSCs based on the new dyes.

The IPCE values are generally below $10 \%$ over the visible region of the spectrum except for those of AS16 and 2 (Fig. 9). The IPCE profiles reflect the absorption profiles of the corresponding dyes; both AS16 and 1 exhibit IPCE maxima coincident with the region in which the complexes have a ${ }^{1}$ MLCTbased absorption band between $400-500 \mathrm{~nm}$. All the other complexes have absorption maxima between 370 and $420 \mathrm{~nm}$ so their IPCE curves show only the tail of these bands into the visible region.

The obtained photovoltaic efficiencies for complexes AS17 and $\mathbf{A S 1 8}$ are lower than those for their $\mathrm{dcbH}_{2}$ analogues determined under identical conditions. This is not unexpected and attributable to their blue-shifted absorption profiles which would result in lower light harvesting efficiency. Further, whilst the LUMO energies for AS16-18 are expected to be in the correct position relative to the $\mathrm{TiO}_{2}$ Fermi level they are higher in energy than those of 1-3. This might imply less efficient overlap of the LUMO with the $\mathrm{TiO}_{2}$ conduction band and consequently lower electron injection efficiency. The best result for the new dyes is obtained for complex AS16 with an efficiency of $0.61 \%$ (compared to $0.1 \%$ for 1 and $5.76 \%$ for the benchmark dye N719 under the same conditions). AS16 achieved the highest open circuit voltage $(0.66 \mathrm{~V})$ which might suggest a longer excited state electron lifetime,${ }^{38}$ hence a higher electron density on the $\mathrm{TiO}_{2}$ surface. The efficiency for AS17 was dramatically lower than that of its $\mathrm{dcbH}_{2}$ analogue 2. Indeed, the efficiency of $2(0.71 \%)$ exceeds that of AS16 with a reasonably strong optical absorption shoulder when adsorbed on $\mathrm{TiO}_{2}$ (ESI $\dagger$ ) that matches the band at $450-550 \mathrm{~nm}$ apparent in the IPCE trace. The rhenium complexes AS18 and 3, however, showed very similar $J_{\mathrm{sc}}, V_{\mathrm{oc}}$ and $\eta$ values to each other.

Table 4 Photovoltaic parameters of tested dyes AS16-18 and 1-3 with N719 as a benchmark comparison in $\mathrm{TiO}_{2}$-based n-type DSSC devices. The electrolyte contained $0.6 \mathrm{M}$ tetrabutylammonium iodide, $0.015 \mathrm{M} \mathrm{I}_{2}$, $0.1 \mathrm{M}$ guanidinium thiocyanate and $0.5 \mathrm{M}$ 4-tert-butylpyridine in $\mathrm{MeCN}$

\begin{tabular}{lclllc}
\hline Dye & $J_{\mathrm{sc}} / \mathrm{mA} \mathrm{cm}^{-2}$ & $V_{\mathrm{oc}} / \mathrm{mV}$ & $\mathrm{FF} / \%$ & $\eta / \%$ & IPCE $/ \%$ \\
\hline N719 & 10.7 & 779 & 69 & 5.76 & 65 \\
1 & 0.39 & 457 & 57 & 0.1 & 6 \\
AS16 & 1.18 & 662 & 78 & 0.61 & 15 \\
2 & 1.44 & 633 & 78 & 0.71 & 17 \\
AS17 & 0.06 & 485 & 72 & 0.02 & 3 \\
3 & 0.36 & 495 & 73 & 0.13 & 6 \\
AS18 & 0.24 & 532 & 73 & 0.09 & 5
\end{tabular}
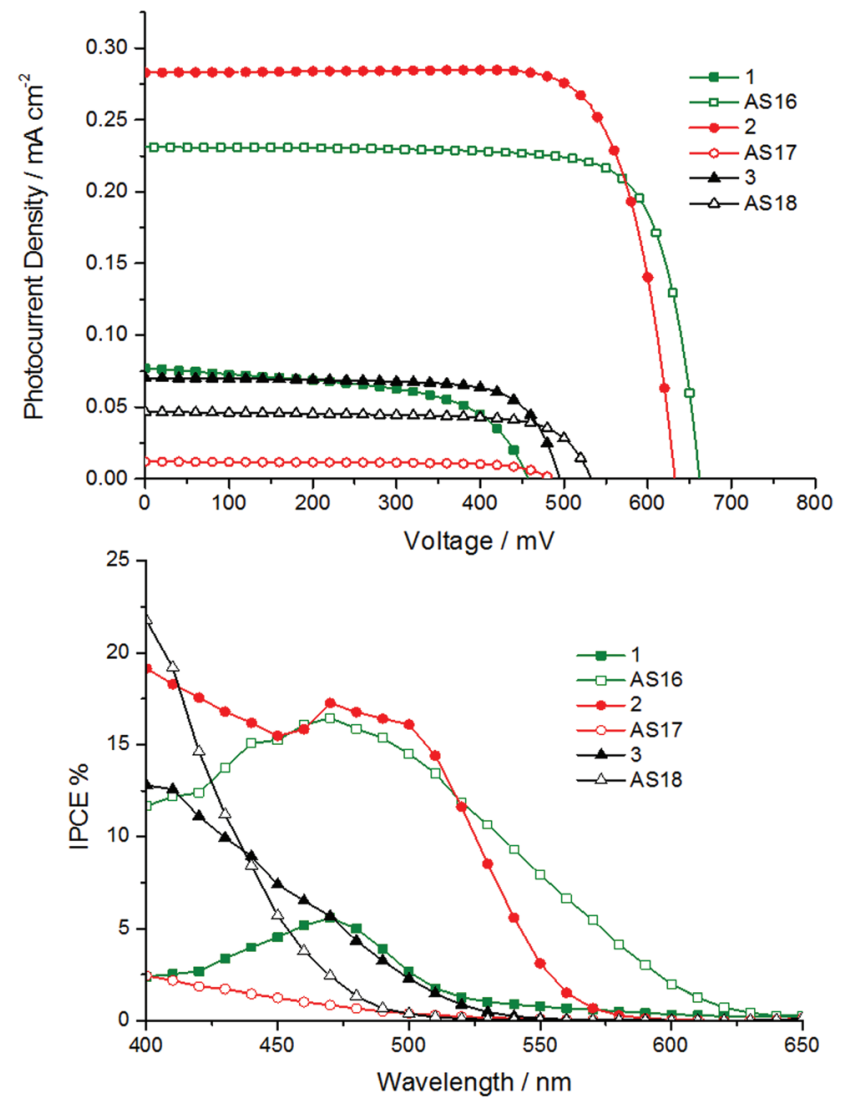

Fig. 9 Current-voltage traces for pilot $\mathrm{TiO}_{2}$-based n-type DSSC devices utilising complexes AS16 to AS18 and model dyes 1 to 3 (top) along with IPCE traces for each cell (bottom). The electrolyte contained $0.6 \mathrm{M}$ tetrabutylammonium iodide, $0.015 \mathrm{M} \mathrm{I}_{2}, 0.1 \mathrm{M}$ guanidinium thiocyanate and 0.5 M 4-tert-butylpyridine in $\mathrm{MeCN}$.

Whilst AS16 indeed shows superior performance over its $\mathrm{dcbH}_{2}$ model in the cells test the performance of the other new dyes, especially in the case of AS17, is disappointing and likely stems from the elevated LUMO associated with the dctzbpy ligand. However, we reasoned that these dyes may yield greater sensitisation efficiency than their $\mathrm{dcbH}_{2}$ analogues in p-type devices for the very same reason. ${ }^{24}$ We therefore constructed and tested NiO-based p-type cells based on the new dyes and their $\mathrm{dcbH}_{2}$ analogues $\mathbf{1}$ to 3 along with coumarin C343 as a benchmark comparison. Current-voltage and IPCE plots are provided in Fig. 10 with photovoltaic parameters listed in Table 5.

The AS16 based cell exhibits the highest overall efficiency of all metal complex sensitised p-type cells $(0.028 \%$ compared to $0.01 \%$ for $\mathrm{C} 343$ ) and the highest IPCE of $17 \%$. As might be expected due to the dctzbpy anchoring ligand being less electron withdrawing than $\mathrm{dcbH}_{2}$ the performances of cells using AS16 and AS17 exceed those of 1 and 2 respectively. Indeed, 1 and 2 seem to be desensitisers of $\mathrm{NiO}$ in these cells with the current generated below $450 \mathrm{~nm}$ most likely stemming from photolysis of the $\mathrm{I}_{3}{ }^{-}$electrolyte as previously noted by Nattestad et al. ${ }^{39}$ Cells utilising AS18 and 3 yield near identical performance parameters. 

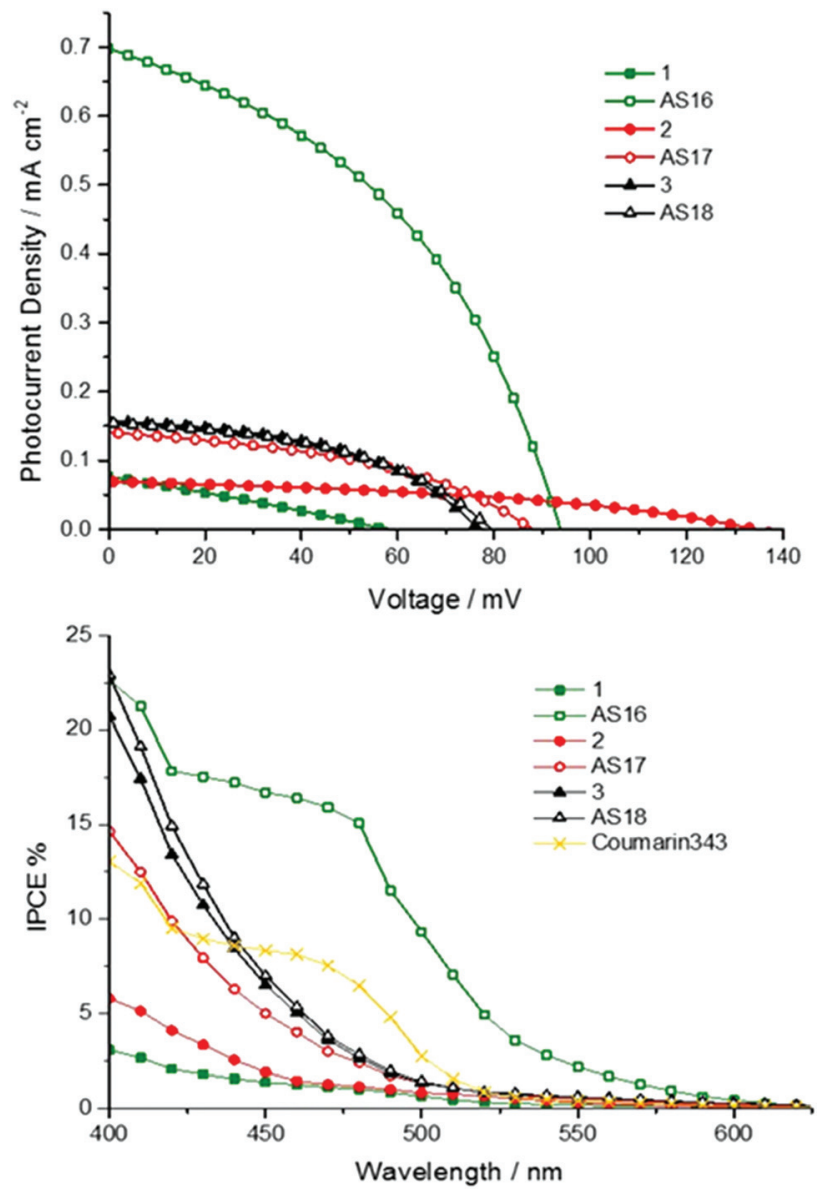

Fig. 10 Current-voltage traces for pilot $\mathrm{NiO}$-based p-type DSSC devices utilising complexes AS16 to AS18 and model dyes 1 to 3 (top) along with IPCE traces for each cell (bottom). The electrolyte contained $0.1 \mathrm{MI}_{2}$ and $1 \mathrm{M} \mathrm{Lil} \mathrm{in} \mathrm{MeCN}$.

Table 5 Photovoltaic parameters of tested dyes AS16-18 and 1-3 with Coumarin-C343 as a benchmark comparison in NiO-based p-type DSSC devices. The electrolyte contained $0.1 \mathrm{M} \mathrm{I}_{2}$ and $1 \mathrm{M}$ Lil in $\mathrm{MeCN}$

\begin{tabular}{llrllc}
\hline Dye & $J_{\text {sc }} / \mathrm{mA} \mathrm{cm}^{-2}$ & $V_{\text {oc }} / \mathrm{mV}$ & $\mathrm{FF} / \%$ & $\eta / \%$ & IPCE $/ \%$ \\
\hline C343 & 0.26 & 105 & 37 & 0.01 & 8 \\
1 & 0.076 & 58 & 27 & 0.0012 & 2 \\
AS16 & 0.69 & 94 & 42 & 0.028 & 17 \\
2 & 0.069 & 134 & 40 & 0.0037 & 3 \\
AS17 & 0.14 & 89 & 42 & 0.0052 & 5 \\
3 & 0.16 & 77 & 45 & 0.0056 & 6 \\
AS18 & 0.15 & 79 & 46 & 0.0055 & 6 \\
& & & & & \\
\hline
\end{tabular}

The results for AS16 are generally encouraging in terms of dye development but are disappointing when considered in comparison to the benchmark N719. With further ancillary ligand development in combination with the new ligand it may be possible to arrive at much higher efficiency n-type sensitisers. Complexes of the new anchoring ligand dctzbpy may also find potential applications in p-type cells since the data show that the ruthenium(II)-based dye AS16 results in an efficiency three times that of the benchmark standard dye coumarin-C343. When combined with other ligands about a metal centre with greater electron withdrawing character this anchoring ligand provides potential for the development of far more efficient p-type sensitisers. Complexes based on the ligands described here may also find utility as photochemical solar fuel catalysts adsorbed on semiconductor nanoparticles. ${ }^{40}$ As the complexes here are luminescent and the carboxylate groups can be utilised for bioconjugation complexes bearing the dctzbpy core structure could also be used in biological imaging applications. ${ }^{41}$

\section{Conclusions}

We have designed and prepared a new anchoring ligand, 1-(2,2'-bipyridin-4-yl)-1,2,3-triazole-4,5-dicarboxylic acid, and its ruthenium, iridium and rhenium complexes. New ruthenium(II), iridium(III) and rhenium(I)-based dyes, AS16 to AS18 respectively, have been compared with their $\mathrm{dcbH}_{2}$ analogues. Spectroscopic and theoretical results suggest the LUMO of the detzbpy ligand is higher in energy than that of $\mathrm{dcbH}_{2}$. Whilst correctly positioned for charge injection upon photoexcitation the resultant blue shift in optical absorption bands results in inferior light harvesting properties. Whilst improved photovoltaic performance is observed for AS16 this leads to a reduction in the photovoltaic efficiency for the other dyes in n-type DSSCs when compared to their $\mathrm{dcbH}_{2}$ analogues. In p-type cells the ruthenium(II) and iridium(III)-based dyes AS16 and AS17 display superior performance over their $\mathrm{dcbH}_{2}$ counterparts. Indeed, AS16 is shown to yield three times the efficiency of the benchmark dye coumarin C343. The work therefore offers insights into new anchor ligand systems. The newly reported ligand has potential for further development for dye complexes in NiO-based p-type DSSC devices especially in which a less electron withdrawing anchoring ligand is desirable, and in other applications including dye-sensitised electrochemical cells for solar catalysis and biological luminescent imaging.

\section{Experimental section}

\section{General methods}

Chemicals were purchased from Aldrich and Acros, iridium and ruthenium were purchased from Precious Metal Online (Australia) and used as received. All complexation reactions were carried out under nitrogen. 4-Azido-2,2'-bipyridine, ${ }^{34}$ $\left[\mathrm{Ru}(\mathrm{bpy})_{2} \mathrm{Cl}_{2}\right],{ }^{24}\left[\operatorname{Ir}(\mathrm{ppy})_{2} \mathrm{Cl}\right]_{2},{ }^{20}\left[\mathrm{Ru}(\mathrm{bpy})_{2}\left(\mathrm{dcbH}_{2}\right)\right]\left[\mathrm{PF}_{6}\right]_{2} \quad(\mathbf{1}),{ }^{18}$ $\left[\operatorname{Ir}(\mathrm{ppy})_{2}\left(\mathrm{dcbH}_{2}\right)\right]\left[\mathrm{PF}_{6}\right](2),{ }^{20}\left[\mathrm{Re}(\mathrm{CO})_{3}(\mathrm{Cl})\left(\mathrm{dcbH}_{2}\right)\right](3),{ }^{17}$ were all prepared according to literature procedures. ${ }^{1} \mathrm{H} \mathrm{NMR}$ and ${ }^{13} \mathrm{C}$ NMR spectra were recorded on a Bruker Avance $400 \mathrm{MHz}$ instrument. Mass spectrometry data were collected on a Bruker Micro Q-TOF instrument. UV-Visible absorption spectra were recorded on a Varian Cary 300 spectrophotometer and corrected emission spectra were recorded on a Horiba Fluoromax-4 spectrofluorometer. Luminescent lifetime measurements were carried out using an Edinburgh Instruments Mini-Tau spectrometer. 


\section{Electrochemistry}

For the cyclic voltammetry a EmStat3 electrochemical interface (Palm Sens, Netherlands) was employed, voltammograms were plotted on PSTrace software (Palm Sens, Netherlands). Cyclic voltammetry was carried out in a single compartment three electrode electrochemical cell under nitrogen atmosphere. Glassy carbon, platinum and $\mathrm{Ag} / \mathrm{AgCl}$ were used respectively as working, counter and reference electrodes. The potential of the tested electrode was measured versus ferrocinium/ferrocene standard internal reference $\left(\mathrm{FeCp}_{2}{ }^{+} / \mathrm{FeCp}_{2}\right)$. The electrolyte used for the cyclic voltammetry measurements was $0.1 \mathrm{M}$ $\mathrm{TBAPF}_{6}$ in acetonitrile, prior to measurements all the solutions were degassed with nitrogen and during measurements a nitrogen blanket was maintained over the solution. The data were then plotted as current $v s$. voltage.

\section{Dye sensitised solar cell fabrication}

FTO glass was used as current collector (TCO30-10, $3 \mathrm{~mm}$ thick glass substrate with a $10 \Omega \mathrm{sq}^{-1}$ ). For $\mathrm{TiO}_{2}$-based anodes cleaned and dried FTO electrodes were immersed into a $40 \mathrm{mM}$ aqueous $\mathrm{TiCl}_{4}$ solution at $70{ }^{\circ} \mathrm{C}$ for 30 minutes and washed with pure water and ethanol and dried. A layer of nanocrystalline $\mathrm{TiO}_{2}$ paste (Solaronix Ti-Nanoxide SP-T) was coated on the FTO glass plates by doctor blade technique, using a round mask ( $5 \mathrm{~mm}$ diameter, $0.25 \mathrm{~cm}^{2}$ area) made by adhesive tape (3M Magic). The film was dried for 5 minutes on a hotplate and a second layer of $\mathrm{TiO}_{2}$ was deposited as before. Following this a light scattering layer (Solaronix Ti-Nanoxide $\mathrm{R} / \mathrm{SP}$ ) was applied in the same way and the films were sintered at $500{ }^{\circ} \mathrm{C}$ for 30 minutes. After a second treatment with $\mathrm{TiCl}_{4}$, the films were sintered for a final time as before. After cooling to $80{ }^{\circ} \mathrm{C}$, the $\mathrm{TiO}_{2}$ electrodes were immersed into a $0.5 \mathrm{mM}$ dye solution in acetonitrile overnight in the dark.

The NiO films were prepared by using an F108-templated precursor solution containing $\mathrm{NiCl}_{2}(1 \mathrm{~g})$, Pluronic ${ }^{\circledR}$ copolymer F108 (1 g), distilled water (3 g) and ethanol (6 g) and the excess was removed by doctor blade. The film was sintered at $450{ }^{\circ} \mathrm{C}$ for 30 minutes and additional layers of precursor solution were applied and sintered until the film thickness was $c a .1 .5 \mu \mathrm{m}$.

The Pt catalyst was deposited on the FTO glass, coating with $10 \mu \mathrm{L} \mathrm{cm}{ }^{-2}$ of $\mathrm{H}_{2} \mathrm{PtCl}_{6}$ solution ( $5 \mathrm{mM}$ ethanol solution), air dried and heated at $400{ }^{\circ} \mathrm{C}$ for 15 minutes. The dye-covered $\mathrm{TiO}_{2}$ or NiO electrodes and Pt-counter electrodes were assembled into a sandwich-type cell and sealed with a Surlyn hot-melt gasket of $60 \mu \mathrm{m}$ thickness. A solution of $0.5 \mathrm{M}$ TBP, $0.015 \mathrm{M} \mathrm{I}_{2}, 0.6 \mathrm{M}$ TBAI and $0.1 \mathrm{M}$ GuSCN in acetonitrile was used as electrolyte in the $\mathrm{TiO}_{2}$-based n-type cells whereas an electrolyte containing $0.1 \mathrm{M} \mathrm{I}_{2}$ and $1 \mathrm{M} \mathrm{LiI}$ in acetonitrile was used for p-type cells.

\section{Computational methods}

DFT calculations were carried out using the NWChem 6.3 software package. ${ }^{42}$ B3LYP hybrid functional (20\% Hartree-Fock) method has been used for calculations, ${ }^{43,44}$ Stuttgart relativis- tic small core $\mathrm{ECP}^{45}$ for transition metals and $6-311 \mathrm{G}^{*}{ }^{46}$ basis sets for all other atoms. Molecular geometries and molecular orbitals pictures were realised using the ccp1 graphical software. For all the studied complexes, the ground state geometries were first optimized and molecular orbital energies determined. TDDFT calculations ${ }^{47}$ on optimised structures in $\mathrm{CH}_{3} \mathrm{CN}$ by using the COSMO solvation model, ${ }^{48}$ built in NWChem software, were used to obtain the electronic spectra and molecular orbital energy levels.

\section{Synthesis of diethyl-1-(2,2'-bipyrid-4-yl)-1,2,3-triazole- 4,5-dicarboxylate}

4-Azido-2,2'-bipyridine $(0.1 \mathrm{~g}, 0.51 \mathrm{mmol})$ and diethyl acetylenedicarboxylate $(0.16 \mathrm{~g}, 0.76 \mathrm{mmol})$ was dissolved in toluene $(15 \mathrm{~mL})$. The solution was allowed to stir at $70{ }^{\circ} \mathrm{C}$ for $24 \mathrm{~h}$. The solvent was removed under vacuum and the product was recrystallised from DCM and hexane to yield a white solid. (175 mg, yield 93\%).

${ }^{1} \mathrm{H}$ NMR $\left(400 \mathrm{MHz}, \mathrm{CDCl}_{3}\right) \delta: 8.85\left(\mathrm{~d},{ }^{3} J=5.28 \mathrm{~Hz}, 1 \mathrm{H}\right.$, py$H$ ); 8.67 (d, ${ }^{3} J=2.08 \mathrm{~Hz}, 1 \mathrm{H}$, py- $H$ ); 8.65 (d, ${ }^{3} J=4.44 \mathrm{~Hz}, 1 \mathrm{H}$, py- $H) ; 8.45$ (d, ${ }^{3} J=7.92 \mathrm{~Hz}, 1 \mathrm{H}$, py- $\left.H\right) ; 7.83\left(\mathrm{td},{ }^{3} J=7.72,{ }^{4} \mathrm{~J}=\right.$ $1.72 \mathrm{~Hz}, 1 \mathrm{H}$, py- $H$ ); 7.61 (dd, ${ }^{3} J=5.28,{ }^{4} J=2.16 \mathrm{~Hz}, 1 \mathrm{H}$, py- $H$ ); 7.43 (ddd, $1 \mathrm{H},{ }^{3} \mathrm{~J}=7.52,{ }^{4} \mathrm{~J}=4.77,{ }^{5} \mathrm{~J}=1.00$, py- $H$ ); 4.47 (q, ${ }^{3} \mathrm{~J}=$ $\left.7.12,2 \mathrm{H}, \mathrm{CH}_{2}-\mathrm{CH}_{3}\right) ; 4.46$ (q, $\left.{ }^{3} J=7.12,2 \mathrm{H}, \mathrm{CH}_{2}-\mathrm{CH}_{3}\right) ; 1.41\left(\mathrm{t},{ }^{3} J\right.$ $\left.=7.12 \mathrm{~Hz}, 3 \mathrm{H}, \mathrm{CH}_{2}-\mathrm{CH}_{3}\right) ; 1.35\left(\mathrm{t},{ }^{3} \mathrm{~J}=7.16 \mathrm{~Hz}, 3 \mathrm{H}, \mathrm{CH}_{2}-\mathrm{CH}_{3}\right)$.

${ }^{13} \mathrm{C}\left\{{ }^{1} \mathrm{H}\right\}$ NMR $\left(100 \mathrm{MHz}, \mathrm{CDCl}_{3}\right) \delta: 159.45,158.90,158.61$, $154.21,150.91,149.38,143.36,139.38,137.12$, 132.45, 124.69, 121.24, 117.37, 114.59, 63.93, 62.09, 14.20, 13.77.

HRMS (ESI) $m / z$ calcd for $\mathrm{C}_{18} \mathrm{H}_{17} \mathrm{~N}_{5} \mathrm{O}_{4}$ 367.1280, found $368.1359(\mathrm{M}+\mathrm{H})^{+}$.

Synthesis of 1-[2,2'-bipyridine-4-yl]triazole-4,5-dicarboxylic acid 1-[2,2'-Bipyridine-4-yl]triazole-4,5-ethyldicarboxylate $\quad(0.1 \mathrm{~g}$, $0.51 \mathrm{mmol}$ ) was dissolved in $25 \mathrm{~mL}$ of $\mathrm{NaOH} 0.1 \mathrm{M}$ and heated to reflux temperature for $4 \mathrm{~h}$, after that the solution was neutralised with $\mathrm{HCl} 2 \mathrm{M}$. A white solid crushed out, collected by filtration and dried under reduced pressure. (134.84 mg, yield $85 \%)$.

${ }^{1} \mathrm{H}$ NMR (400 MHz, DMSO-d $\left.{ }_{6}\right) \delta: 8.96\left(\mathrm{~d},{ }^{3} J=5.24,1 \mathrm{H}\right.$, py$H) ; 8.77\left(\mathrm{~d},{ }^{3} J=4.72,1 \mathrm{H}\right.$, py- $\left.H\right) ; 8.61\left(\mathrm{~d},{ }^{4} J=1.36,1 \mathrm{H}\right.$, py- $H$ ); $8.54\left(\mathrm{~d},{ }^{3} J=7.96,1 \mathrm{H}\right.$, py- $\left.H\right) ; 8.15\left(\mathrm{t},{ }^{3} J=7.64,1 \mathrm{H}\right.$, ру- $\left.H\right) ; 7.81$ $\left(\mathrm{d},{ }^{3} J=5.20,{ }^{4} J=1.72,1 \mathrm{H}, \mathrm{py}-H\right) ; 7.64\left(\mathrm{t},{ }^{3} J=5.48,1 \mathrm{H}\right.$, py- $\left.H\right)$.

${ }^{13} \mathrm{C}\left\{{ }^{1} \mathrm{H}\right\}$ NMR (100 MHz, DMSO-d 6$) \quad \delta: 160.67,158.62$, $155.34,152.77,150.66,148.55$, 144.94, 139.97, 139.14, 134.14, 125.4, 121.45, 120.7, 116.84 .

HRMS (ESI) $m / z$ calcd for $\mathrm{C}_{14} \mathrm{H}_{9} \mathrm{~N}_{5} \mathrm{O}_{4}$ 311.0654, found $310.0582(\mathrm{M}-\mathrm{H})^{-}$.

\section{Synthesis of $\left[\mathrm{Ru}(\mathrm{bpy})_{2}\right.$ (diethyl-1-(2,2'-bipyrid-4-yl)-1,2,3-tri- azole-4,5-dicarboxylate $)]\left(\mathrm{PF}_{6}\right)_{2} \mathrm{AS16}_{\mathbf{2}}$}

$100 \mathrm{mg}$ of $\mathrm{Ru}(\mathrm{bpy})_{2} \mathrm{Cl}_{2}$ were dissolved in EtOH $(20 \mathrm{~mL})$ together with $113 \mathrm{mg}$ of dectzbpy. The solution was heated to reflux temperature overnight, under $\mathrm{N}_{2}$ in the dark. The solvent was removed under reduced pressure and the resulting solid dissolved in $\mathrm{MeOH}$, an excess of $\mathrm{NH}_{4} \mathrm{PF}_{6}$ was added and an orange crystalline solid was collected by filtration. The solid 
was columned on silica gel with $\mathrm{MeCN}: \mathrm{H}_{2} \mathrm{O}: \mathrm{KNO}_{3} 7: 1: 0.5$ as eluent. The main gloving fraction was then dried, redissolved in acetonitrile and filtered. The filtrate was dried and redissolved in a minimum amount of methanol, $\mathrm{NH}_{4} \mathrm{PF}_{6}$ was added, an orange solid crashed and it was collected by filtration. (168.1 mg, yield 76\%).

${ }^{1} \mathrm{H}$ NMR (400 MHz, $\left.\mathrm{CD}_{3} \mathrm{CN}\right) \delta: 8.79\left(\mathrm{~d},{ }^{3} J=2.02,1 \mathrm{H}, \mathrm{bpy}-H\right)$; 8.55-8.49 (m, 5H, bpy- $H$ ); 8.12-8.05 (m, 5H, bpy- $H$ ); 7.96 (d, ${ }^{3} J$ $=6.15,1 \mathrm{H}$, bpy- $H) ; 7.83\left(\mathrm{~d},{ }^{3} J=5.32,1 \mathrm{H}\right.$, bpy- $\left.H\right) ; 7.78\left(\mathrm{~d},{ }^{3} J=\right.$ 5.53, 1H, bpy- $H$ ); 7.76-7.69 (m, 3H, bpy-H); 7.55 (dd, ${ }^{3} J=6.15$, ${ }^{3} J=2.20,1 \mathrm{H}$, bpy- $\left.H\right) ; 7.48-7.39(\mathrm{~m}, 5 \mathrm{H}, \mathrm{bpy}-H) ; 4.43\left(\mathrm{q},{ }^{3} J=\right.$ $\left.7.16,2 \mathrm{H}, \mathrm{CH}_{2}-\mathrm{CH}_{3}\right) ; 4.31\left(\mathrm{q},{ }^{3} \mathrm{~J}=7.07,2 \mathrm{H}, \mathrm{CH}_{2}-\mathrm{CH}_{3}\right) 1.37$ $\left(\mathrm{t},{ }^{3} \mathrm{~J}=7.12,3 \mathrm{H}, \mathrm{CH}_{2}-\mathrm{CH}_{3}\right) ; 1.11\left(\mathrm{t},{ }^{3} \mathrm{~J}=7.03,3 \mathrm{H}, \mathrm{CH}_{2}-\mathrm{CH}_{3}\right)$.

${ }^{13} \mathrm{C}\left\{{ }^{1} \mathrm{H}\right\} \mathrm{NMR}\left(100 \mathrm{MHz}, \mathrm{CD}_{3} \mathrm{CN}\right) \delta: 159.54 ; 159.10 ; 157.74 ;$ $156.97,156.96 ; 156.93$, 156.92; 156.88, 156.87; 156.83; 156.05; $153.52 ; 152.00 ; 151.94 ; 151.91 ; 151.83 ; 151.65 ; 143.10 ; 140.54$, $138.19 ; 138.10 ; 138.09 ; 137.94,128.41 ; 127.78 ; 127.74 ; 127.70$; $127.62 ; 125.12 ; 125.08,124.48 ; 124.43 ; 122.04 ; 119.67 ; 63.75$; $62.25 ; 13.40 ; 13.04$.

HRMS (ESI) $m / z$ calcd for $\left[\mathrm{C}_{38} \mathrm{H}_{33} \mathrm{~N}_{9} \mathrm{O}_{4} \mathrm{Ru}\right]^{2+} 390.5860$, found $390.5864(\mathrm{M})^{2+}$.

\section{Synthesis of $\left[\mathrm{Ru}(\mathrm{bpy})_{2}\left(1-\left[2,2^{\prime}\right.\right.\right.$-bipyridine-4-yl] triazole-4,5-ethyl- dicarboxylic acid)] $\mathrm{PF}_{6}$ AS16}

$50 \mathrm{mg}$ of $\left[\mathrm{Ru}(\mathrm{bpy})_{2}(\right.$ detzbpy $\left.)\right]\left(\mathrm{PF}_{6}\right)_{2}$ was dissolved in $8 \mathrm{~mL} 1 \mathrm{M}$ $\mathrm{KOH} /$ acetone $1: 1$ and heated to reflux temperature for 12 hours. After cooling the acetone was removed under vacuum and the solution was neutralised with $1 \mathrm{M} \mathrm{HCl}$. The solution was concentrated and a solid crashed out. The solid was collected by filtration, redissolved in a minimal amount of methanol and $\mathrm{NH}_{4} \mathrm{PF}_{6}$ was added, newly a red solid crashed and it was collected by filtration. (35.5 mg, yield 75\%).

${ }^{1} \mathrm{H}$ NMR (400 MHz, $\left.\mathrm{CD}_{3} \mathrm{CN}\right) \delta: 8.76\left(\mathrm{~d},{ }^{3} J=2.08,1 \mathrm{H}, \mathrm{bpy}-H\right)$; 8.55-8.46 (m, 5H, bpy-H); 8.13-8.03 (m, 5H, bpy- $H$ ); 7.92 (d, ${ }^{3} J$ $=6.12,1 \mathrm{H}, \mathrm{bpy}-H) ; 7.83-7.70(\mathrm{~m}, 5 \mathrm{H}, \mathrm{bpy}-H) ; 7.61\left(\mathrm{~d},{ }^{3} J=6.12\right.$, ${ }^{4} J=2.2,1 \mathrm{H}$, bpy- $\left.H\right) ; 7.51-7.40$ (m, 5H, bpy- $\left.H\right)$.

${ }^{13} \mathrm{C}\left\{{ }^{1} \mathrm{H}\right\}$ NMR $\left(100 \mathrm{MHz}, \mathrm{CD}_{3} \mathrm{CN}\right) \delta: 159.68,159.63,159.21$, 157.86, 157.03, 156.99, 156.94, 156.90, 156.88, 156.46, 156.23, $154.69,152.38,151.89,151.86,151.84,151.82$, 151.81, 151.62, 143.42, 138.08, 138.03, 138.00, 137.96, 128.03, 127.73, 127.72, 127.66, 127.65, 124.75, 124.43, 124.40, 124.31, 121.72, 120.59 .

Synthesis of $\left[\operatorname{Ir}(\mathrm{ppy})_{2}\right.$ (diethyl-1-(2,2'-bipyrid-4-yl)-1,2,3-triazole4,5-dicarboxylate)] $\mathrm{PF}_{6} \mathrm{AS}$ - $-\mathrm{Et}_{2}$

$107 \mathrm{mg}$ of $\left[\operatorname{Ir}(\mathrm{ppy})_{2} \mathrm{Cl}\right]_{2}$ dimer were dissolved in DCM : $\mathrm{MeOH}$ $2: 1(12 \mathrm{~mL})$ together with $77 \mathrm{mg}$ of detzbpy and $53 \mathrm{mg}$ of $\mathrm{AgPF}_{6}$. The solution was heated to reflux temperature overnight, under $\mathrm{N}_{2}$ in the dark. The solvent was removed under reduced pressure and the resulting solid dissolved in DCM and filtered on celite pad. The solvent was removed again and the solid recrystallised from acetonitrile/ether. A pale orange solid was collected by filtration and columned with $10 \%$ MeOH in DCM. (149.3 mg, yield 74\%).

${ }^{1} \mathrm{H}$ NMR (400 MHz, $\left.\mathrm{CD}_{3} \mathrm{CN}\right) \delta: 8.81\left(\mathrm{~d},{ }^{3} J=1.70,1 \mathrm{H}, \mathrm{bpy}-H\right)$; $8.54\left(\mathrm{~d},{ }^{3} J=8.04,1 \mathrm{H}\right.$, bpy- $\left.H\right) ; 8.20-8.13(\mathrm{~m}, 2 \mathrm{H}, \mathrm{bpy}-H) ; 8.08$ (d, ${ }^{3} J=8.14,2 \mathrm{H}$, ppy- $\left.H\right) ; 8.02\left(\mathrm{dd},{ }^{3} J=5.78,{ }^{4} J=0.78,1 \mathrm{H}\right.$, bpy- $H$; $7.86\left(\mathrm{td},{ }^{3} J=7.35,{ }^{4} J=0.84,2 \mathrm{H}, \mathrm{ppy}-H\right) ; 7.82\left(\mathrm{~d},{ }^{3} J=7.62,2 \mathrm{H}\right.$, ppy- $H) ; 7.72\left(\mathrm{dd},{ }^{3} J=5.52,{ }^{3} J=0.81,1 \mathrm{H}, \mathrm{ppy}-H\right) ; 7.65\left(\mathrm{dd},{ }^{3} J=\right.$ $6.09,{ }^{4} J=2.17,1 \mathrm{H}$, bpy- $\left.H\right) ; 7.63\left(\mathrm{dd},{ }^{3} J=5.96,{ }^{4} J=0.81,1 \mathrm{H}\right.$, bpy- $H$ ); $7.56\left(\mathrm{t},{ }^{3} J=6.30,1 \mathrm{H}\right.$, bpy- $\left.H\right)$; 7.09-7.02 (m, 4H, ppy- $H$ ); 6.96-6.90 (m, 2H, ppy- $H$ ); 6.29 (dd, ${ }^{3} J=7.75,{ }^{4} J=0.88,1 \mathrm{H}$, ppy$H) ; 6.26\left(\mathrm{dd},{ }^{3} J=7.63,{ }^{4} \mathrm{~J}=0.74,1 \mathrm{H}, \mathrm{ppy}-H\right) ; 4.42\left(\mathrm{q},{ }^{3} \mathrm{~J}=6.95\right.$, $2 \mathrm{H}, \mathrm{CH}_{2}-\mathrm{CH}_{3}$ ); 4.31 (qd, ${ }^{3} \mathrm{~J}=7.10,{ }^{4} \mathrm{~J}=1.15,2 \mathrm{H}, \mathrm{CH}_{2}-\mathrm{CH}_{3}$ ); $1.36\left(\mathrm{t},{ }^{3} \mathrm{~J}=7.10,3 \mathrm{H}, \mathrm{CH}_{2}-\mathrm{CH}_{3}\right) ; 1.10\left(\mathrm{t},{ }^{3} \mathrm{~J}=7.10,3 \mathrm{H}\right.$, $\left.\mathrm{CH}_{2}-\mathrm{CH}_{3}\right)$.

${ }^{13} \mathrm{C}\left\{{ }^{1} \mathrm{H}\right\}$ NMR (100 MHz, CD 3 CN) $\delta: 167.35,167.24,159.48$, 158.15 , 157.72, 154.72, 152.48, 150.99, 149.52, 149.49, 149.43, $144.40,144.09,143.97,140.50,139.62,138.78,138.72,131.80$, $131.59,131.44,130.49,130.44,129.26,125.37,124.98,124.95$, 123.66, 123.54, 123.08, 122.82, 122.76, 120.10, 120.01, 119.98, 63.81, 62.24, 13.39, 12.97 .

HRMS (ESI) $m / z$ calcd for $\left[\mathrm{C}_{40} \mathrm{H}_{33} \mathrm{~N}_{7} \mathrm{O}_{4} \mathrm{Ir}\right]^{+}$867.2230, found $867.2228\left(\mathrm{M}^{+}\right)$.

Synthesis of $\left[\operatorname{Ir}(\mathrm{ppy})_{2}\left(1-\left[2,2^{\prime}\right.\right.\right.$-bipyridine-4-yl $]$ triazole-4,5-ethyldicarboxylate)] $\mathrm{PF}_{6} \mathrm{AS}_{7}$

$50 \mathrm{mg}$ of $\mathbf{A S 1 7}_{-\mathbf{E t}_{2}}$ was dissolved in $8 \mathrm{~mL} 1 \mathrm{M} \mathrm{KOH} /$ acetone $1: 1$ and heated to reflux temperature for 12 hours. After cooling the acetone was removed under vacuum and the solution was neutralised with $1 \mathrm{M} \mathrm{HCl}$. The solution was concentrated and a solid crashed out. The solid was collected by filtration, redissolved in a minimal amount of methanol and $\mathrm{NH}_{4} \mathrm{PF}_{6}$ was added, newly a yellow solid crashed and it was collected by filtration. (32.1 mg, yield 68\%).

${ }^{1} \mathrm{H}$ NMR (400 MHz, CD $\left.{ }_{3} \mathrm{CN}\right) \delta: 8.46\left(\mathrm{~d},{ }^{3} J=6.56 \mathrm{~Hz}, 1 \mathrm{H}\right.$, bpy- $H) ; 8.11\left(\mathrm{td},{ }^{3} J=6.28,{ }^{4} J=1.24 \mathrm{~Hz}, 1 \mathrm{H}, \mathrm{bpy}-H\right) ; 8.07\left(\mathrm{t},{ }^{3} J=\right.$ $5.64 \mathrm{~Hz}, 2 \mathrm{H}, \mathrm{ppy}-H) ; 8.00$ (bs, $1 \mathrm{H}, \mathrm{bpy}-H) ; 7.97\left(\mathrm{dd},{ }^{3} \mathrm{~J}=4.3,{ }^{4} \mathrm{~J}=\right.$ $0.8 \mathrm{~Hz}, 1 \mathrm{H}$, bpy-H); 7.89-7.84 (m, 2H, ppy- $H$ ); 7.81 (d, ${ }^{3} J=6.08$ $\mathrm{Hz}, 2 \mathrm{H}, \mathrm{ppy}-H) ; 7.71\left(\mathrm{~d},{ }^{3} J=4.72 \mathrm{~Hz}, 1 \mathrm{H}, \mathrm{bpy}-H\right) ; 7.65\left(\mathrm{~d},{ }^{3} J=\right.$ $4.6 \mathrm{~Hz}, 1 \mathrm{H}$, ppy- $H) ; 7.63\left(\mathrm{~d},{ }^{3} J=5.16 \mathrm{~Hz}, 1 \mathrm{H}, \mathrm{ppy}-H\right) ; 7.47\left(\mathrm{td},{ }^{3} J\right.$ $\left.=5.24,{ }^{4} J=0.72 \mathrm{~Hz}, 1 \mathrm{H}, \mathrm{bpy}-H\right) ; 7.09-7.02$ (m, 5H, bpy-H\&ppy$H)$; 6.97-6.9 (m, 3H, ppy-H); $6.31\left(\mathrm{dd},{ }^{3} J=6.06,{ }^{4} J=0.6 \mathrm{~Hz}, 1 \mathrm{H}\right.$, pрy- $H) ; 6.28$ (dd, ${ }^{3} J=6.04,{ }^{4} J=0.52 \mathrm{~Hz}, 1 \mathrm{H}$, ppy- $H$ ).

${ }^{13} \mathrm{C}\left\{{ }^{1} \mathrm{H}\right\} \mathrm{NMR}\left(100 \mathrm{MHz}, \mathrm{CD}_{3} \mathrm{CN}\right) \delta: 167.63,167.49,157.16$, 156.23, 151.26, 150.45, 149.14, 149.11, 144.28, 144.06, 139.99, $139.88,139.86,139.84,139.21$, 139.16, 138.36, 138.33, 131.91, $131.67,131.65,131.51,130.31,130.27,130.23$, 128.11, 124.82, $124.78,124.33,123.4,123.37,122.32,122.3$.

\section{Synthesis of $\operatorname{Re}(\mathrm{CO})_{3}($ diethyl-1-(2,2'-bipyrid-4-yl)-1,2,3-triazole-} 4,5-dicarboxylate)Cl AS18-Et

$100 \mathrm{mg}$ of $\left[\mathrm{Re}(\mathrm{CO})_{5} \mathrm{Cl}\right]$ and $113 \mathrm{mg}$ of detzbpy were dissolved in $25 \mathrm{~mL}$ of toluene and heated at $70^{\circ} \mathrm{C}$ for 12 hours. After cooling the volume was reduced under reduced pressure and a yellow solid crashed out, it was collected by filtration and dried with diethylether. (155.8 mg, yield 84\%).

${ }^{1} \mathrm{H}$ NMR (400 MHz, CD $\left.3 \mathrm{CN}\right) \delta: 9.21\left(\mathrm{~d},{ }^{3} J=5.96,1 \mathrm{H}, \mathrm{bpy}-H\right)$; $9.06\left(\mathrm{dd},{ }^{3} J=5.38,{ }^{3} J=0.70,1 \mathrm{H}, \mathrm{bpy}-H\right) ; 8.70\left(\mathrm{~d},{ }^{3} J=2.10,1 \mathrm{H}\right.$, bpy- $H$ ); 8.44 (d, ${ }^{3} J=8.18,1 \mathrm{H}$, bpy- $\left.H\right) ; 8.23$ (dt, ${ }^{3} J=7.951 .52$, $1 \mathrm{H}, \mathrm{bpy}-H) ; 7.78\left(\mathrm{dd},{ }^{3} \mathrm{~J}=6.08,{ }^{3} \mathrm{~J}=2.34,1 \mathrm{H}, \mathrm{bpy}-H\right) ; 7.69\left(\mathrm{dt},{ }^{3} J\right.$ $=6.49,{ }^{3} J=1.22,1 \mathrm{H}$, bpy- $\left.H\right) ; 4.44\left(\mathrm{q},{ }^{3} J=7.13,2 \mathrm{H}, \mathrm{CH}_{2}-\mathrm{CH}_{3}\right)$; 
$4.41\left(\mathrm{q},{ }^{3} \mathrm{~J}=7.02,2 \mathrm{H}, \mathrm{CH}_{2}-\mathrm{CH}_{3}\right) ; 1.38\left(\mathrm{t},{ }^{3} \mathrm{~J}=7.13,3 \mathrm{H}, \mathrm{CH}_{2}-\right.$ $\left.\mathrm{CH}_{3}\right) ; 1.27\left(\mathrm{t},{ }^{3} \mathrm{~J}=6.98,3 \mathrm{H}, \mathrm{CH}_{2}-\mathrm{CH}_{3}\right)$.

${ }^{13} \mathrm{C}\left\{{ }^{1} \mathrm{H}\right\}$ NMR (100 MHz, CD3CN) $\delta: 197.63,197.47,189.26$, 159.55 , 157.96, 157.87, 154.73, 154.65, 153.25, 144.91, 140.59, 140.22 , 131.79, 128.29, 124.65, 121.86, 119.36, 63.94, 62.24, 13.40, 13.07 .

HRMS (ESI) $\mathrm{m} / \mathrm{z}$ calcd for $\mathrm{C}_{21} \mathrm{H}_{17} \mathrm{ClN}_{5} \mathrm{O}_{7} \mathrm{Re} 671.0352$, found $689.0694\left(\mathrm{M}+\mathrm{NH}_{4}\right)^{+}$.

\section{Synthesis of $\operatorname{Re}(\mathrm{CO})_{3}\left(1-\left[2,2^{\prime}\right.\right.$-bipyridine-4-yl] triazole-4,5-ethyldi- carboxylate)Cl AS18}

$50 \mathrm{mg}$ of $\left[\mathrm{Re}(\mathrm{CO})_{3}(\right.$ detzbpy $\left.) \mathrm{Cl}\right]$ was dissolved in $8 \mathrm{~mL} 1 \mathrm{M}$ $\mathrm{KOH} /$ acetone $1: 1$ and heated to reflux temperature for 12 hours. After cooling the acetone was removed under vacuum and the solution was neutralised with $1 \mathrm{M} \mathrm{NaOH}$. The solution was concentrated and a yellow solid crashed out. The solid was collected by filtration. (30.7 mg, yield 67\%).

${ }^{1} \mathrm{H}$ NMR (400 MHz, DMSO-d 6 ) $\delta: 8.94\left(\mathrm{~d},{ }^{3} J=5.44,1 \mathrm{H}, \mathrm{bpy}-H\right.$ ); $8.44\left(\mathrm{~d},{ }^{3} J=8.17,1 \mathrm{H}\right.$, bpy- $\left.H\right) ; 8.22\left(\mathrm{t},{ }^{3} J=7.78,1 \mathrm{H}\right.$, bpy- $\left.H\right) ; 7.97$ $\left(\mathrm{d},{ }^{3} J=6.81,1 \mathrm{H}, \mathrm{bpy}-H\right) ; 7.63\left(\mathrm{t},{ }^{3} J=6.61,1 \mathrm{H}, \mathrm{bpy}-H\right) ; 7.15\left(\mathrm{~d},{ }^{3} J=\right.$ $2.25,1 \mathrm{H}, \mathrm{bpy}-H) ; 6.14$ (dd, ${ }^{3} J=6.95,{ }^{4} J=2.64,1 \mathrm{H}, \mathrm{bpy}-H$ ).

${ }^{13} \mathrm{C}\left\{{ }^{1} \mathrm{H}\right\}$ Low solubility, NMR not recorded.

\section{Acknowledgements}

The authors wish to thank the Leverhulme Trust and the University of Huddersfield for funding this research. As a member of the UK Materials Chemistry Consortium PIPE also thank the EPRSC (EP/L000202) and the UK HPC national resource, Archer, as well as the University of Huddersfield High Performance Computing Research Group for computational resources utilised in this project.

\section{References}

1 A. Hagfeldt, G. Boschloo, L. Sun, L. Kloo and H. Pettersson, Chem. Rev., 2010, 110, 6595-6663.

2 M. K. Nazeeruddin, E. Baranoff and M. Grätzel, Sol. Energy, 2011, 85, 1172-1178.

3 B. O'Regan and M. Gratzel, Nature, 1991, 353, 737-740.

4 S. Ardo and G. J. Meyer, Chem. Soc. Rev., 2009, 38, 115-164.

5 A. Juris, V. Balzani, F. Barigelletti, S. Campagna, P. Belser and A. V. Zelewsky, Coord. Chem. Rev., 1988, 84, 85-277.

6 W. B. Heuer, H.-L. Xia, W. Ward, Z. Zhou, W. H. Pearson, M. A. Siegler, A. A. Narducci Sarjeant, M. Abrahamsson and G. J. Meyer, Inorg. Chem., 2012, 51, 3981-3988.

7 S. Altobello, R. Argazzi, S. Caramori, C. Contado, S. Da Fré, P. Rubino, C. Choné, G. Larramona and C. A. Bignozzi, J. Am. Chem. Soc., 2005, 127, 15342-15343.

8 E. A. M. Geary, L. J. Yellowlees, L. A. Jack, I. D. H. Oswald, S. Parsons, N. Hirata, J. R. Durrant and N. Robertson, Inorg. Chem., 2005, 44, 242-250.

9 G. M. Hasselmann and G. J. Meyer, Z. Phys. Chem., 1999, 212, 39-44.
10 S. Ferrere, Chem. Mater., 2000, 12, 1083-1089.

11 E. Baranoff, J.-H. Yum, M. Graetzel and M. K. Nazeeruddin, J. Organomet. Chem., 2009, 694, 2661-2670.

12 A. Yella, H. W. Lee, H. N. Tsao, C. Yi, A. K. Chandiran, M. K. Nazeeruddin, E. W. G. Diau, C. Y. Yeh, S. M. Zakeeruddin and M. Grätzel, Science, 2011, 334, 629634.

13 A. Mishra, M. K. R. Fischer and P. Büuerle, Angew. Chem., Int. Ed., 2009, 48, 2474-2499.

14 Z. Yao, M. Zhang, H. Wu, L. Yang, R. Li and P. Wang, J. Am. Chem. Soc., 2015, 137, 3799-3802.

15 J. B. Goodenough, J. Phys. Chem., 1982, 86, 3492-3492.

16 F. De Angelis, S. Fantacci, E. Mosconi, M. K. Nazeeruddin and M. Grätzel, J. Phys. Chem. C, 2011, 115, 8825-8831.

17 A. Mishra, N. Pootrakulchote, M. K. R. Fischer, C. Klein, M. K. Nazeeruddin, S. M. Zakeeruddin, P. Bauerle and M. Gratzel, Chem. Commun., 2009, 7146-7148.

18 M. Abrahamsson, P. G. Johansson, S. Ardo, A. Kopecky, E. Galoppini and G. J. Meyer, J. Phys. Chem. Lett., 2010, 1725-1728.

19 P. Wang, C. Klein, J.-E. Moser, R. Humphry-Baker, N.-L. Cevey-Ha, R. Charvet, P. Comte, S. M. Zakeeruddin and M. Grätzel, J. Phys. Chem. B, 2004, 108, 17553-17559.

20 I. Gillaizeau-Gauthier, F. Odobel, M. Alebbi, R. Argazzi, E. Costa, C. A. Bignozzi, P. Qu and G. J. Meyer, Inorg. Chem., 2001, 40, 6073-6079.

21 A. Buttner, S. Y. Brauchli, R. Vogt, E. C. Constable and C. E. Housecroft, RSC Adv., 2016, 6, 5205-5213.

22 S. Altobello, C. A. Bignozzi, S. Caramori, G. Larramona, S. Quici, G. Marzanni and R. Lakhmiri, J. Photochem. Photobiol., A, 2004, 166, 91-98.

23 F. Odobel, L. Le Pleux, Y. Pellegrin and E. Blart, Acc. Chem. Res., 2010, 43, 1063-1071.

24 F. Odobel, Y. Pellegrin, E. A. Gibson, A. Hagfeldt, A. L. Smeigh and L. Hammarström, Coord. Chem. Rev., 2012, 256, 2414-2423.

25 J. Massin, S. Lyu, M. Pavone, A. B. Munoz-Garcia, B. Kauffmann, T. Toupance, M. Chavarot-Kerlidou, V. Artero and C. Olivier, Dalton Trans., 2016, 45, 1253912547.

26 M. Gennari, F. Légalité, L. Zhang, Y. Pellegrin, E. Blart, J. Fortage, A. M. Brown, A. Deronzier, M.-N. Collomb, M. Boujtita, D. Jacquemin, L. Hammarström and F. Odobel, J. Phys. Chem. Lett., 2014, 5, 2254-2258.

27 C. J. Wood, K. C. D. Robson, P. I. P. Elliott, C. P. Berlinguette and E. A. Gibson, RSC Adv., 2014, 4, 5782-5791.

28 Z. Ji, G. Natu, Z. Huang, O. Kokhan, X. Zhang and Y. Wu, J. Phys. Chem. C, 2012, 116, 16854-16863.

29 Y. Pellegrin, L. Le Pleux, E. Blart, A. Renaud, B. Chavillon, N. Szuwarski, M. Boujtita, L. Cario, S. Jobic, D. Jacquemin and F. Odobel, J. Photochem. Photobiol., A, 2011, 219, 235242 .

30 A. Sinopoli, C. J. Wood, E. A. Gibson and P. I. P. Elliott, Eur. J. Inorg. Chem., 2016, 2887-2890.

31 T. P. Lodge, Macromol., 2009, 42, 3827-3829. 
32 E. Lim, Int. J. Photoenergy, 2013, 2013, 607826, DOI: 10.1155/2013/607826.

33 D. Schweinfurth, K. I. Hardcastle and U. H. F. Bunz, Chem. Commun., 2008, 2203-2205.

34 R. A. Fallahpour, Helv. Chim. Acta, 2000, 83, 384-393.

35 B. S. Uppal, A. Zahid and P. I. P. Elliott, Eur. J. Inorg. Chem., 2013, 2571-2579.

36 G. M. Hasselmann and G. J. Meyer, J. Phys. Chem. B, 1999, 103, 7671-7675.

37 E. I. Mayo, K. Kilsa, T. Tirrell, P. I. Djurovich, A. Tamayo, M. E. Thompson, N. S. Lewis and H. B. Gray, Photochem. Photobiol. Sci., 2006, 5, 871-873.

38 T. N. Murakami, N. Koumura, M. Kimura and S. Mori, Langmuir, 2014, 30, 2274-2279.

39 A. Nattestad, M. Ferguson, R. Kerr, Y.-B. Cheng and U. Bach, Nanotechnology, 2008, 19, 295304.

40 M. K. Brennaman, R. J. Dillon, L. Alibabaei, M. K. Gish, C. J. Dares, D. L. Ashford, R. L. House, G. J. Meyer,
J. M. Papanikolas and T. J. Meyer, J. Am. Chem. Soc., 2016, 138, 13085-13102.

41 K. K.-W. Lo and S. P.-Y. Li, RSC Adv., 2014, 4, 10560-10585.

42 M. Valiev, E. J. Bylaska, N. Govind, K. Kowalski, T. P. Straatsma, H. J. J. V. Dam, D. Wang, J. Nieplocha, E. Apra, T. L. Windus and W. d. Jong, Comput. Phys. Commun., 2010, 181, 1477-1660.

43 P. J. Stephens, F. J. Devlin, C. F. Chabalowski and M. J. Frisch, J. Phys. Chem., 1994, 98, 11623-11627.

44 A. D. Becke, J. Chem. Phys., 1983, 98, 5648-5652.

45 D. Andrae, U. Haussermann, M. Dolg, H. Stoll and H. Preuss, Theor. Chim. Acta, 1990, 77, 123-141.

46 R. Krishnan, J. S. Binkley, R. Seeger and J. A. Pople, J. Chem. Phys., 1980, 72, 650-654.

47 E. Runge and E. K. U. Gross, Phys. Rev. Lett., 1984, 52, 9971000.

48 A. Klamt and G. Schuurmann, J. Chem. Soc., Perkin Trans. 2, 1993, 799-805. 